\title{
Ecosystem greenspots pass the first test
}

\author{
Susan F. Gould • Sonia Hugh • \\ Luciana L. Porfirio • Brendan Mackey
}

Received: 6 January 2014/ Accepted: 19 October 2014/Published online: 28 October 2014

(C) The Author(s) 2014. This article is published with open access at Springerlink.com

\begin{abstract}
Given climate change projections, the ability to identify locations that provide refuge under drought conditions is an urgent conservation priority. Previously, it has been proposed that the ecosystem greenspot index could be used to identify locations that currently function as habitat refuges from drought and fire. If this is true, these locations may have the potential to function as climate-change micro-refuges. In this study we aimed to: (1) test whether ecosystem greenspot indices are related to vegetation specific gradients of habitat resources; and (2) identify environmental correlates of the ecosystem greenspots. Ecosystem greenspot indices were calculated for two vegetation types: a woodland and a grassland, and compared with in situ data on vegetation structure. There were inaccuracies in the identification of the grassland greenspot index due to fine scale spatial heterogeneity and misclassification. However, the woodland greenspot index accurately identified vegetation specific gradients in the biomass of the relevant
\end{abstract}

\section{S. F. Gould $(\bowtie) \cdot$ B. Mackey}

Griffith Climate Change Response Program, Griffith

University, Science, Engineering and Architecture

Building (G39), Gold Coast Campus, Parklands Drive,

Southport, QLD 4222, Australia

e-mail: s.gould@griffith.edu.au

\section{S. Hugh · L. L. Porfirio}

Fenner School of Environment and Society, The Australian National University, Building 141 Linnaeus

Way, Canberra, ACT 0200, Australia framework species. The spatial distribution of woodland greenspots was related to interacting rainfall, soil and landscape variables. The ability to provide information about variation in resources, and hence habitat quality, within specific vegetation types has immediate applications for conservation planning. This is the first step toward validating whether the ecosystem greenspot index of Mackey et al. (Ecol Appl 22:1852-1864, 2012) can identify potential drought micro-refuges. More work is needed to (1) address sources of error in identifying specific vegetation types; (2) refine the analysis and field validation methods for grasslands; and (3) to test whether species persistence during drought is supported by identified greenspots.

Keywords Climate change $\cdot$ fPAR $\cdot$ Framework species $\cdot$ Micro-refuges $\cdot$ NDVI $\cdot$ Primary productivity - Vegetation based habitat resources . Tasmania $\cdot$ Australia

\section{Introduction}

Climate projections indicate that drought frequency and severity is likely to increase over much of eastern Australia over the coming century (Hennessy et al. 2007; White et al. 2010). In evolutionary terms, species can respond in one of three ways to changing environmental conditions: extinction, adaptation or 
stasis. Evidence from the Pleistocene shows that species responses to climatic oscillations varied with topography, latitude and individual species characteristics (Hewitt 2004). However, the most typical response was evolutionary stasis in situ combined with changes in distribution and abundance (Stewart and Lister 2001; Byrne 2008; Magri 2008; Provan and Bennett 2008; Kearns et al. 2010). Locations where conditions are such that species can persist in situ while their populations are generally contracting in range or abundance have been termed cryptic refugia and micro-refuges. Given climate change projections, the ability to identify potential climate change microrefuges is a research and conservation priority (Keppel et al. 2011; Sublette Mosblech et al. 2011).

Refugia are conceptualised as locations that provide protection from extreme or protracted climatic conditions and are potential source areas for population expansion if conditions outside the refuge become suitable again. There is ongoing debate about terminology (Rull 2009; Stewart et al. 2010; Keppel et al. 2011), with differences primarily based on spatial and temporal scale. Irrespective of the terminology used, refugia are necessarily specific to the type of disturbance (Berryman and Hawkins 2006) and the species of interest (Ashcroft 2010). The actual area required for populations to persist in situ will vary with the intensity and duration of the disturbance, and the life history attributes of the species.

Recent research has focussed on identifying topographically driven micro-climates as potential climate change refuges (Ashcroft et al. 2009, 2012; Ashcroft 2010; Dobrowski 2011). Landscape genetics and phylogeographic analyses are also being used to identify the locations of historical refugia (Hugall et al. 2002; Carnaval et al. 2009; Scoble and Lowe 2010). An alternative approach proposes that locations where mean plant productivity is relatively high and temporally stable compared to other locations of the same vegetation classification could potentially function as drought refuges (Mackey et al. 2012). The theoretical basis for this proposal rests (1) on the general relationship that exists between plant productivity, resources, population size and extinction risk, and (2) on the matching that occurs between species and the habitats that they occupy (Southwood 1988).

Population size is primarily determined by the interaction of the space-time distribution of resources, species' physiological and life history attributes, and local environmental conditions (Gates 1980; Andrewartha and Birch 1984). The same principle applies to plants and animals because population size is mechanistically connected to resources through metabolism and allometric scaling laws (Enquist et al. 1998, 1999; Carbone and Gittleman 2002; West and Brown 2005). The specific mechanisms that link resources with population size vary depending on how and where the per capita effects on species' survival and fecundity are the greatest (Huston 1994; Newton 2013). For example, the numbers of several species of migrant European songbirds fluctuate according to rainfall (and hence food supplies) in their African wintering grounds (Newton 2004); and the availability of nesting sites can limit the numbers of hollow nesting birds (Newton 1994). Irrespective of the specific mechanism, as populations become smaller they become more vulnerable to extinction through demographic and environmental stochasticity (Caughley 1994; Gaggiotti and Hanski 2004). Mackey et al. (2012) proposed that variability in the distribution and availability of habitat resources could be represented by space/time variability in vegetation productivity.

Gross primary productivity (GPP), the rate per unit area at which new biomass is produced by the vegetation cover, can be monitored remotely using time series of satellite images (Box 1989). NASA's Moderate Resolution Imaging Spectroradiometer (MODIS) sensor detects the energy reflected in distinct spectral bands from every part of the Earth's surface every 1-2 days. Reflectance values are used to calculate the normalised difference vegetation index (NDVI) which has been shown to be sensitive to spatial and temporal variation in the amount of vegetation and its' condition (Huete et al. 2002). The fraction of photosynthetically active radiation absorbed by a sunlit canopy (fPAR) which is a reliable proxy for GPP (Berry and Roderick 2004) can be derived from the NDVI.

Mackey et al. (2012) demonstrated the potential application of time series of fPAR to the identification of ecosystem greenspots, i.e., locations that maintain relatively high and stable levels of gross primary productivity (GPP) during drought. Integrating the spatial and temporal dimensions of productivity has also been applied to continental scale habitat analysis in relation to dispersive fauna in Australia (Berry et al. 2007), biodiversity monitoring in Canada (Coops et al. 2008), and seasonal dynamics of habitat quality of 


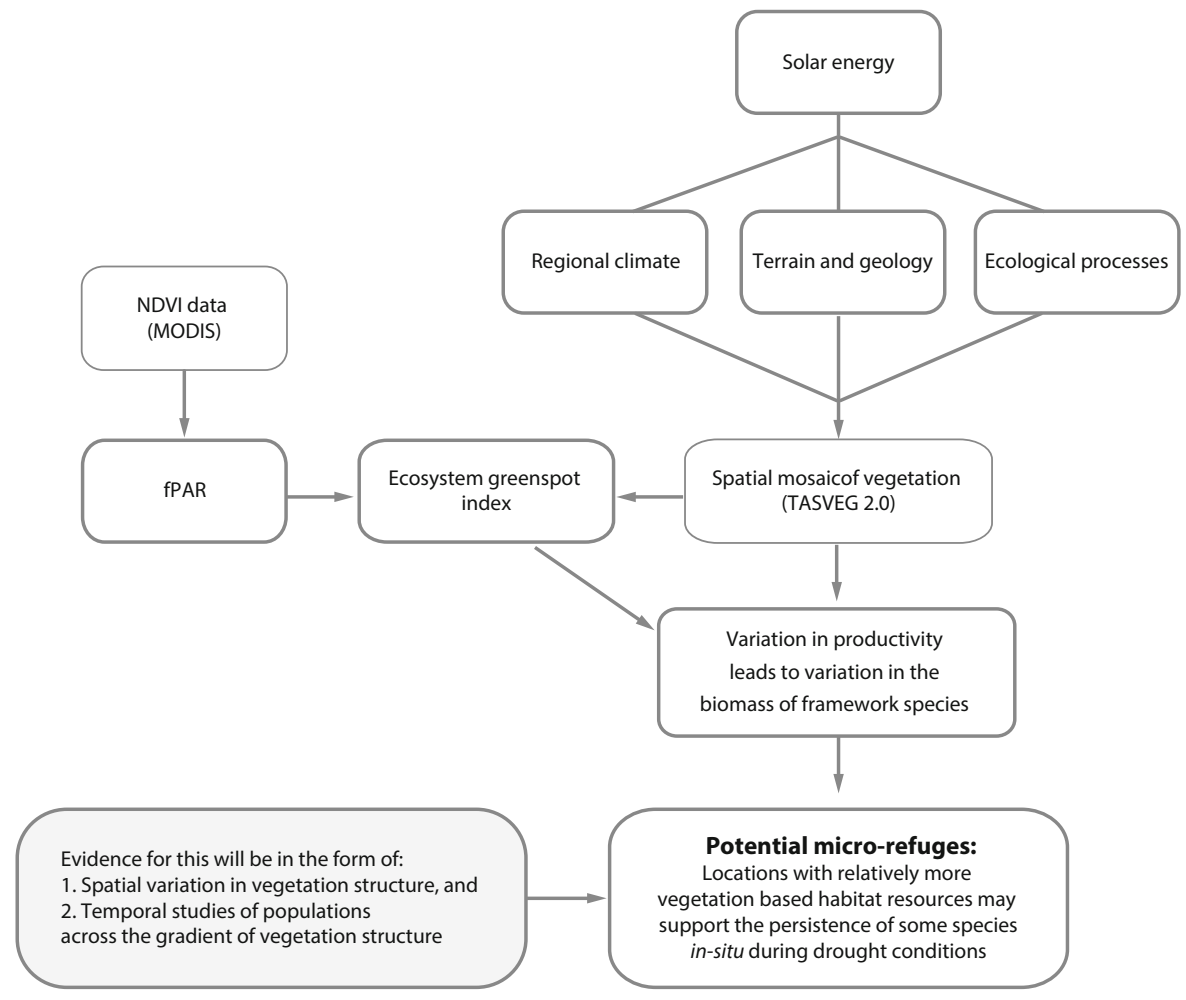

Fig. 1 Conceptual diagram of the relationships between fPAR, the ecosystem greenspots index and potential micro-refuges. The fraction of photosynthetically active radiation absorbed by a sunlit canopy (fPAR), which is derived from NDVI, is a reliable proxy for gross primary productivity (GPP). We assume that for any given vegetation type (represented by vegetation maps),

brown bears in Spain (Wiegand et al. 2008). Mackey et al. (2012) proposed that the ecosystem greenspot index could be used to identify locations that currently function as habitat refuges from fire and drought which in some bioregions are likely to become more persistent under future climatic conditions. If this is true, these locations may have the potential to function as climate change micro-refuges. A conceptual diagram of relationships is shown in Fig. 1. The ecosystem greenspots index, however, awaits validation with in situ data.

Validation of the ecosystem greenspots index requires at least two lines of supporting evidence. First, vegetation data are needed to test whether the ecosystem greenspots index is related to vegetation specific gradients in the amount of habitat resources and not simply an artefact of classification error or weed infestation. Second, demographic and dispersal studies of potential beneficiary species are needed to higher long term mean productivity and more temporally stable productivity (represented by fPAR) will be reflected in the biomass of specific framework species. In turn, the resources provided by these framework species may help sustain populations in situ during drought conditions

test whether species persistence during drought is supported by the identified greenspot locations. In this study, we aimed to test whether the ecosystem greenspots index can accurately identify habitat specific gradients in the amount of vegetation based habitat resources. We also analysed how landscape and climatic variables were related to the spatial distribution of ecosystem greenspot classes. This study represents the first step towards validating ecosystem greenspots as a tool for identifying potential drought micro-refuges.

\section{Data and methods}

The study area

The Northern Midlands of Tasmania, Australia, was selected as the location for validating the ecosystem 
Fig. 2 Location of study area. The shaded area indicates the Northern Midlands bioregion

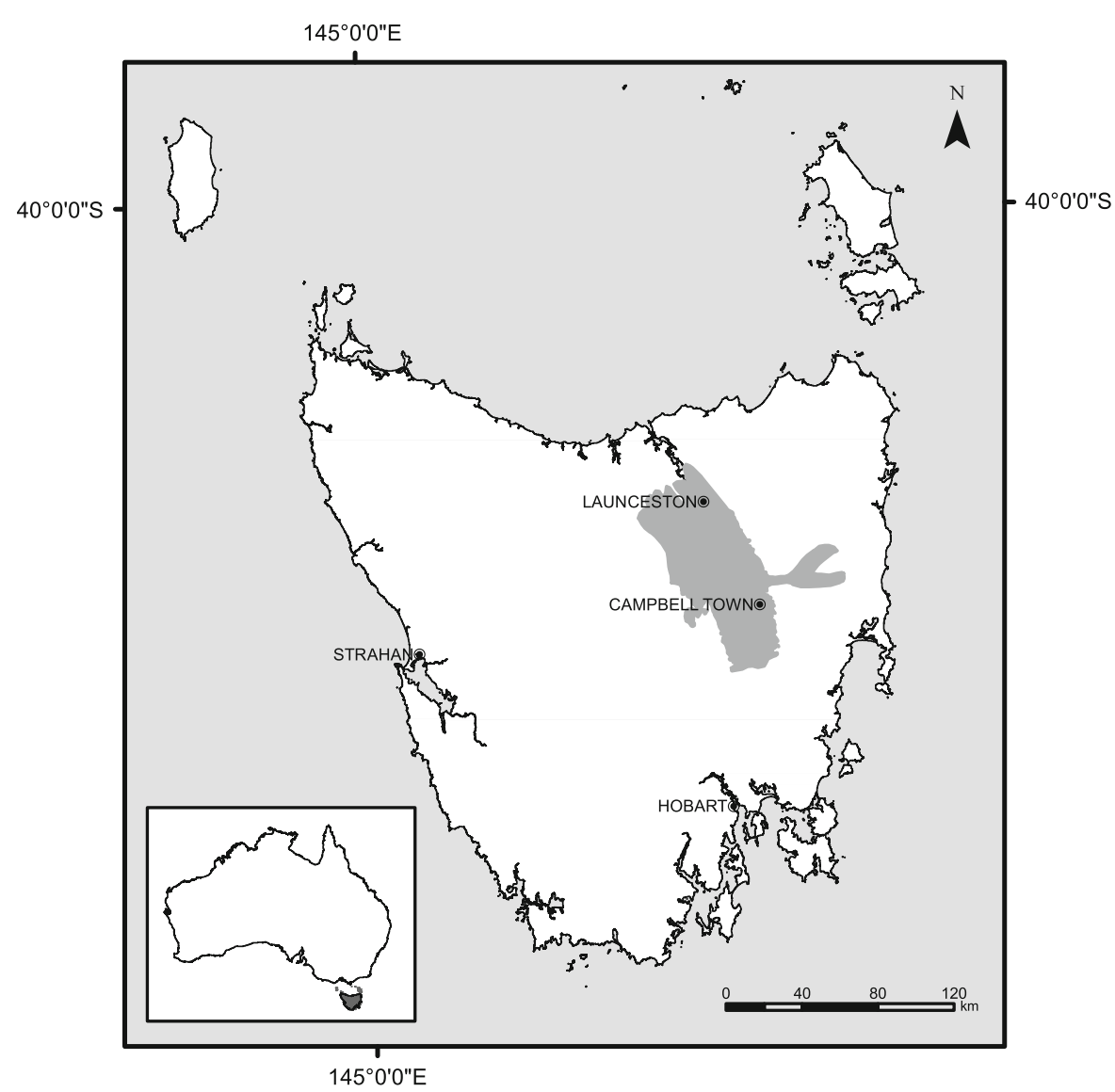

greenspot index as it is currently the focus of research into regional scale conservation planning tools (Fig. 2). Two critically endangered ecosystems and many vulnerable, endangered and critically endangered species occur in the Northern Midlands bioregion.

\section{Calculating the ecosystem greenspot index}

Vegetation specific greenspot indices were calculated by combining spatial vegetation data with a time series of fPAR. To calculate the fPAR time series we followed methods that were originally developed for a pre-cursor of the MODIS NDVI by Sellers et al. (1994) then followed by (Roderick et al. 1999; Berry and Roderick 2002, 2004; Mackey et al. 2012). Methods for calculating the ecosystem greenspot index are outlined in detail in Mackey et al. (2012). We used this method rather than the available fPAR MOD15A2 product because it provides higher geographic resolution, i.e.,
$250 \mathrm{~m}$ compared with the resolution of global data which is $500 \mathrm{~m}$. Furthermore, the method of Mackey et al. (2012) does additional processing to remove cloud contamination that is present in the global data and has been corrected to derive a soil adjusted value for Australian conditions. The resulting index identifies potential greenspots within six percentiles for each specific vegetation type within a defined area of interest. The greenspot analysis was restricted to the Northern Midlands bioregion. Index thresholds corresponding to the 10, 25, 50, 75, 90 and 95th percentiles were calculated for each vegetation type.

The source for the NDVI data was NASA's MODIS sensor, 16 day L3 Global $250 \mathrm{~m}$ MOD13Q1 for the period June 2000-July 2011. This period incorporated record low rainfall periods in the Northern Midlands including record low annual rainfall (2008), and record low monthly rainfall totals for February (2003), June (2007), October (2008) and November (2006) (Bureau of Meteorology 2013). 
1 (a)

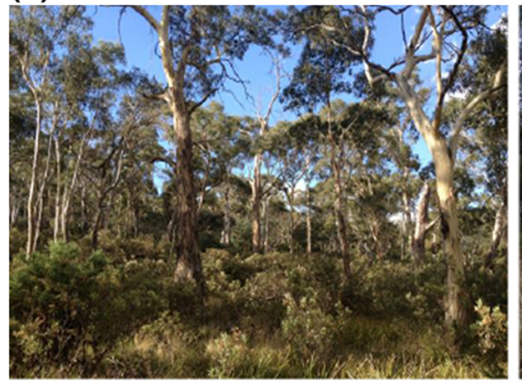

2 (a)

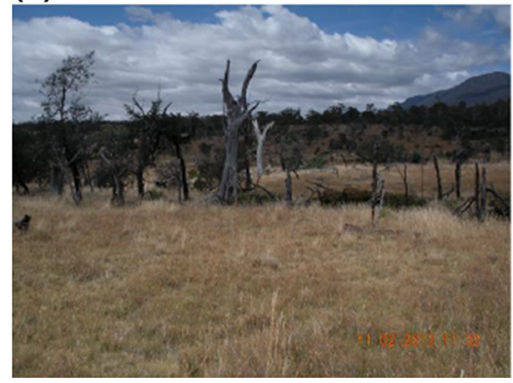

(b)

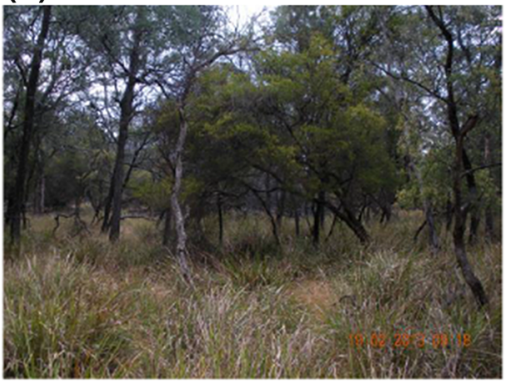

(b)

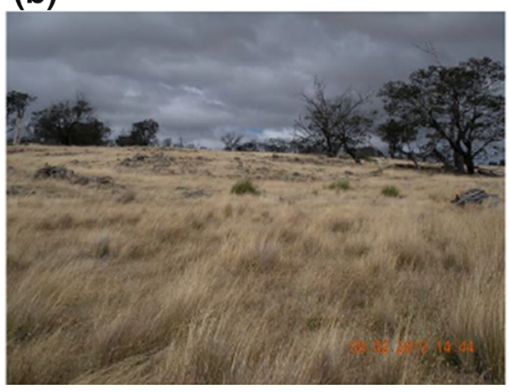

(c)

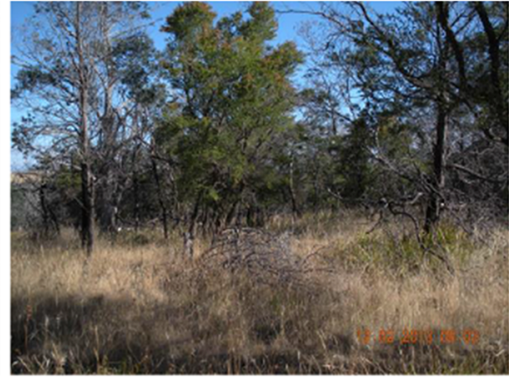

(c)

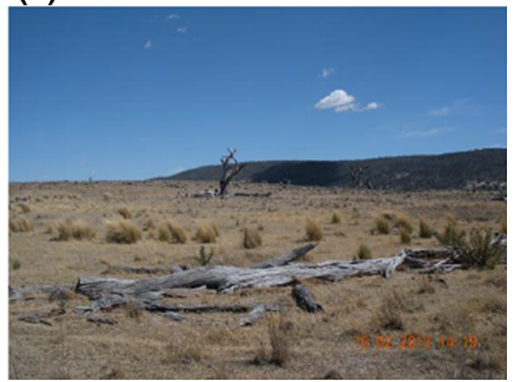

Fig. 3 Variation within the two study ecosystems. Photos represent the (a) top, (b) middle, and (c) low greenspot groups for (1) Eucalyptus viminalis grassy forest/woodland, and (2) lowland Themeda triandra grassland respectively

Vegetation data were sourced from TASVEG Version 2.0 (Tasmanian Vegetation Monitoring and Mapping Program 2009), a state-wide coverage at a cartographic scale of 1:25,000. Vector vegetation data were rasterized at $250 \mathrm{~m}$ resolution to match the resolution of the fPAR data and each grid cell was classified according to the vegetation type at the cell centre. The final output was a raster coverage in which each polygon had two attributes: (i) the vegetation type, and (ii) a greenspot index percentile calculated for the specific vegetation type within the bioregion.

\section{Study design}

To test whether the productivity gradient that underlies the ecosystem greenspot index is related to vegetation specific gradients of habitat resources we quantified vegetation structure within two vegetation types: (i) Eucalyptus viminalis grassy forest/woodland (henceforth woodland); and (ii) lowland Themeda triandra grassland (henceforth grassland). These vegetation types represent two broad vegetation categories that dominated the pre-European and extant native vegetation in the Northern Midlands of Tasmania (Fig. 3). We selected sites to sample across the ecosystem greenspot
Table 1 Sample size of vegetation types and greenspot percentiles

\begin{tabular}{llllllll}
\hline Vegetation type & \multicolumn{7}{c}{ Ecosystem greenspot percentiles } \\
\cline { 2 - 8 } & 10 & 25 & 50 & 75 & 90 & 95 & Total \\
\hline Woodland & 1 & 2 & 2 & 2 & 3 & 1 & 11 \\
Grassland & 0 & 0 & 2 & 2 & 5 & 2 & 11 \\
\hline
\end{tabular}

index within each vegetation type subject to site accessibility (Table 1).

We used the biomass of relevant framework species as a surrogate for vegetation specific gradients in the amount habitat resources. Framework species, also referred to as foundation species (Ellison et al. 2005) and structural species (Huston 1994), are the species that dominate the structure and function of an ecosystem. Because of their structural dominance, the identity of framework species is often used as the basis for vegetation classification. Framework species influence the micro-climatic conditions and provide the bulk of vegetation based habitat resources used by interstitial species. The relevant framework species were E. viminalis in the woodland and T. triandra in the grassland. 
Within each site, we sampled vegetation within square plots of $200 \mathrm{~m}^{2}$ located to avoid pixel boundaries. For each plot the positions of fifteen random sampling points were generated and uploaded into a GPS for location in the field. At each sampling point, we collected data for three a priori vegetation layers: (i) tussock grasses/sedges; (ii) a middle layer of woody vegetation; and (iii) a canopy layer of woody vegetation. The middle and canopy vegetation layers were defined differently for grasslands and woodlands because of differences in vegetation structure. In grasslands, the middle layer was defined as woody vegetation $<2 \mathrm{~m}$ in height whereas in forest/woodland sites the middle layer was defined as woody vegetation $<5 \mathrm{~m}$ in height. Data were collected using the pointquarter method and a radius truncated to $15 \mathrm{~m}$. The point-quarter method is a plotless sampling method that is widely used in vegetation sampling. The method is described and illustrated in Krebs (1997).

In each quarter we collected the following data for each vegetation layer: distance to individual; species identity; height; canopy length; and canopy width. In addition, we measured diameter at the base for tussock grasses/sedges and diameter at breast height (DBH) for the canopy layer of woody vegetation. This method potentially provides 60 distance measures per vegetation layer per site. For the middle and canopy layers, distance to the closest individual was measured. For tussock grasses/sedges, distance to the second-closest individual was measured. Distance to the secondclosest individual is preferred as it provides a smaller sampling variance than distance to the closest individual (Pollard 1971; Engeman et al. 1994), however, densities of shrubs and trees were too low to use the second-closest individual method. All vegetation data were collected during February 2013.

\section{Data analysis}

Site means were calculated for each vegetation layer and where necessary, data were transformed to meet assumptions of normality. We calculated stem densities using Morisita's point-based estimator which is more robust to spatial non-randomness than other commonly used procedures (Mitchell 2007; Bouldin 2008). The fPAR variables used to represent the amount of productivity and the temporal stability of productivity were long term mean PPAR and coefficient of variation of monthly mean fPAR. We used linear regression to test whether site vegetation variables were related to site fPAR variables. To test for differences between groups of woodland greenspots we used ANOVA. Woodland greenspots were grouped as follows for ANOVA, top $=10$ and 25th percentiles $(\mathrm{n}=3)$, middle $=50$ and 75 th percentile $(\mathrm{n}=4)$, and low $=90$ and 95th percentile $(\mathrm{n}=4)$. All data analysis was conducted in R (R Development Core Team 2005).

We used recursive binary partitioning to analyse the spatial distribution of woodland greenspots in relation to environmental variables. Recursive partitioning embeds tree structured regression models into conditional inference procedures and thereby reduces overfitting and biased variable selection (Hothorn et al. 2006). The resulting tree and leaf nodes mean that groups can be identified based on interactions between explanatory variables. Recursive partitioning procedures improve on linear regression by allowing for interactions and non-linearities when there are multiple explanatory variables and are useful for spatial mapping (Prasad et al. 2006). The analysis included all $250 \mathrm{~m}$ pixels classified as E. viminalis grassy forest/ woodland within the Northern Midlands bioregion $(\mathrm{n}=5,428)$. Woodland greenspots were grouped as follows for recursive partitioning: top $=10$ and 25 th percentiles $(\mathrm{n}=149)$, middle $=50$ and 75 th percentiles $(\mathrm{n}=1,852)$, low $=90$ and 95th percentiles $(\mathrm{n}=2,592)$ and bottom $=$ all remaining sites lower than the 95th percentile $(\mathrm{n}=835)$. Potentially explanatory variables included in the analysis were: annual mean rainfall, topographic slope angle, topographic aspect, topographic position and plant available water capacity (Table 2). The procedure was performed with the rpartv4.1-8 package in $\mathrm{R}$ using the default values.

\section{Results}

Woodlands greenspot index

Field observations confirmed that the mapped vegetation data were accurate in that sites that had been mapped as woodlands were found to be woodlands. Within woodland sites, however, there was variation in vegetation structure and species turnover between sites. In particular, the composition of the shrub layer varied between woodland sites and included exotic species, especially Gorse (Ulex europaeus). The 
Table 2 Potentially explanatory variables used to analyse the spatial distribution of greenspots

\begin{tabular}{|c|c|c|}
\hline Variable & Units & Source \\
\hline $\begin{array}{l}\text { Annual mean } \\
\text { rainfall }\end{array}$ & $\begin{array}{l}\text { Millimetres }(\mathrm{mm}) \text { : } \\
\text { min. } 441.9, \text { max. } \\
\text { 1,077.2, mean } 635.3\end{array}$ & ANUClim \\
\hline $\begin{array}{l}\text { Plant } \\
\text { available } \\
\text { water } \\
\text { capacity }\end{array}$ & $\begin{array}{l}\text { Index }(0-1) \text { derived } \\
\text { from: soil field } \\
\text { texture; \% and } \\
\text { porosity of coarse } \\
\text { fragments; bulk } \\
\text { density; layer } \\
\text { thickness; depth to } \\
\text { impeding layer; } \\
\text { volumetric water } \\
\text { content at }-10 \mathrm{kPa} \\
\text { (notional field } \\
\text { capacity) and } \\
\text { - 1.5 MPa (notional } \\
\text { wilting point) }\end{array}$ & $\begin{array}{l}\text { Australian soil } \\
\text { resource } \\
\text { Information System } \\
\text { (ASRIS) provided at } \\
250 \text { m resolution }\end{array}$ \\
\hline $\begin{array}{l}\text { Topographic } \\
\text { slope angle }\end{array}$ & $\begin{array}{l}\text { Degrees }\left({ }^{\circ}\right) \text { : } \min . \\
0.004, \max .26 .6, \\
\text { mean } 2.7\end{array}$ & $\begin{array}{l}\text { Derived from the } \\
\text { Australian } 3 \mathrm{~s} \text { DEM } \\
\text { and resampled to } \\
250 \mathrm{~m} \text { resolution }\end{array}$ \\
\hline $\begin{array}{l}\text { Topographic } \\
\text { aspect }\end{array}$ & $\begin{array}{l}\text { Eight directional } \\
\text { classes: north } \\
\text { (337.5-22.5), } \\
\text { northeast } \\
(22.5-67.5), \text { east } \\
(67.5-112.5), \\
\text { southeast } \\
\text { (112.5-157.5), } \\
\text { south } \\
\text { (157.5-202.5), } \\
\text { southwest } \\
(202.5-247.5), \text { west } \\
\text { (247.5-292.5), } \\
\text { northwest } \\
\text { (292.5-337.5 }\end{array}$ & $\begin{array}{l}\text { Derived from the } \\
\text { Australian } 3 \mathrm{~s} \mathrm{DEM} \\
\text { and resampled to } \\
250 \mathrm{~m} \text { resolution }\end{array}$ \\
\hline $\begin{array}{l}\text { Topographic } \\
\text { position }\end{array}$ & $\begin{array}{l}\text { Seven classes: } \\
\text { (i) ridge tops (ii) } \\
\text { upper slopes (iii) } \\
\text { mid slopes (iv) } \\
\text { lower slopes } \\
\text { (v) valley fill in } \\
\text { upland landscapes } \\
\text { (vi) rises in lowland } \\
\text { alluvial fill or long } \\
\text { gentle sloping foot } \\
\text { slopes (vii) large } \\
\text { expanses of in-filled } \\
\text { valleys and alluvial } \\
\text { depositions }\end{array}$ & $\begin{array}{l}\text { Derived from the } \\
\text { Australian } 3 \mathrm{~s} \text { DEM } \\
\text { and resampled to } \\
250 \mathrm{~m} \text { resolution }\end{array}$ \\
\hline
\end{tabular}

woodland greenspot index correctly identified a gradient in woodland vegetation structure. E. viminalis formed a canopy at sites in the high woodland
Table 3 Results from linear regressions on fPAR

\begin{tabular}{|c|c|c|c|c|}
\hline Vegetation variable & $\begin{array}{l}\text { fPAR } \\
\text { variable }\end{array}$ & $\begin{array}{l}\text { Adj R }{ }^{2} \\
(9 \text { df. })\end{array}$ & $F$ & $p$ \\
\hline \multicolumn{5}{|l|}{ Woodland } \\
\hline \multirow[t]{2}{*}{$\begin{array}{l}\text { Basal area of } E . \\
\quad \text { viminalis (sqrt) }\end{array}$} & $\begin{array}{l}\text { Long term } \\
\text { mean }\end{array}$ & 0.60 & 16.11 & 0.003 \\
\hline & $\begin{array}{l}\mathrm{CV} \\
\text { monthly } \\
\text { mean }\end{array}$ & 0.08 & 1.92 & $0.19 \mathrm{~ns}$ \\
\hline \multirow[t]{2}{*}{ Height of tree layer } & $\begin{array}{l}\text { Long term } \\
\text { mean }\end{array}$ & 0.62 & 17.48 & 0.002 \\
\hline & $\begin{array}{l}\mathrm{CV} \\
\text { monthly } \\
\text { mean }\end{array}$ & 0.06 & 1.74 & $0.21 \mathrm{~ns}$ \\
\hline \multicolumn{5}{|l|}{ Grassland } \\
\hline \multirow{2}{*}{$\begin{array}{l}\text { Basal area of } \\
\text { tussock grasses } \\
\text { (sqrt) }\end{array}$} & $\begin{array}{l}\text { Long term } \\
\text { mean }\end{array}$ & -0.08 & 0.21 & $0.65 \mathrm{~ns}$ \\
\hline & $\begin{array}{l}\mathrm{CV} \\
\text { monthly } \\
\text { mean }\end{array}$ & 0.38 & 7.32 & 0.02 \\
\hline \multirow{2}{*}{$\begin{array}{l}\text { Basal area of } \\
\text { Themeda triandra } \\
\text { (sqrt) }\end{array}$} & $\begin{array}{l}\text { Long term } \\
\text { mean }\end{array}$ & -0.06 & 0.38 & $0.55 \mathrm{~ns}$ \\
\hline & $\begin{array}{l}\text { CV } \\
\text { monthly } \\
\text { mean }\end{array}$ & 0.32 & 5.79 & 0.03 \\
\hline
\end{tabular}

Sqrt square root transformed, $n s$ non-significant

greenspot group but occurred as isolated emergent trees at sites in the low woodland greenspot group (Fig. 3). Site values for the basal area of the framework species, E. viminalis, and height of the tree layer were significantly positively related to long term mean fPAR but not to the coefficient of variation of monthly mean fPAR (Table 3). Differences between groups of woodland greenspots were significant for the basal area of E. viminalis $(F=9.59, p<0.007)$ and for the height of the canopy layer $(F=4.65, p<0.05)$ (Fig. 4).

Grasslands greenspot index

There was a high error rate of vegetation classification for grasslands as many sites that were mapped as grasslands were found to have a substantial component of shrubland and woodland vegetation. Sites in the highest percentile of the grassland greenspot index attained their high values because of the presence of shrublands and woodlands in sites that had been mapped as grasslands. After removing sites that included patches of shrubland and woodland we only 


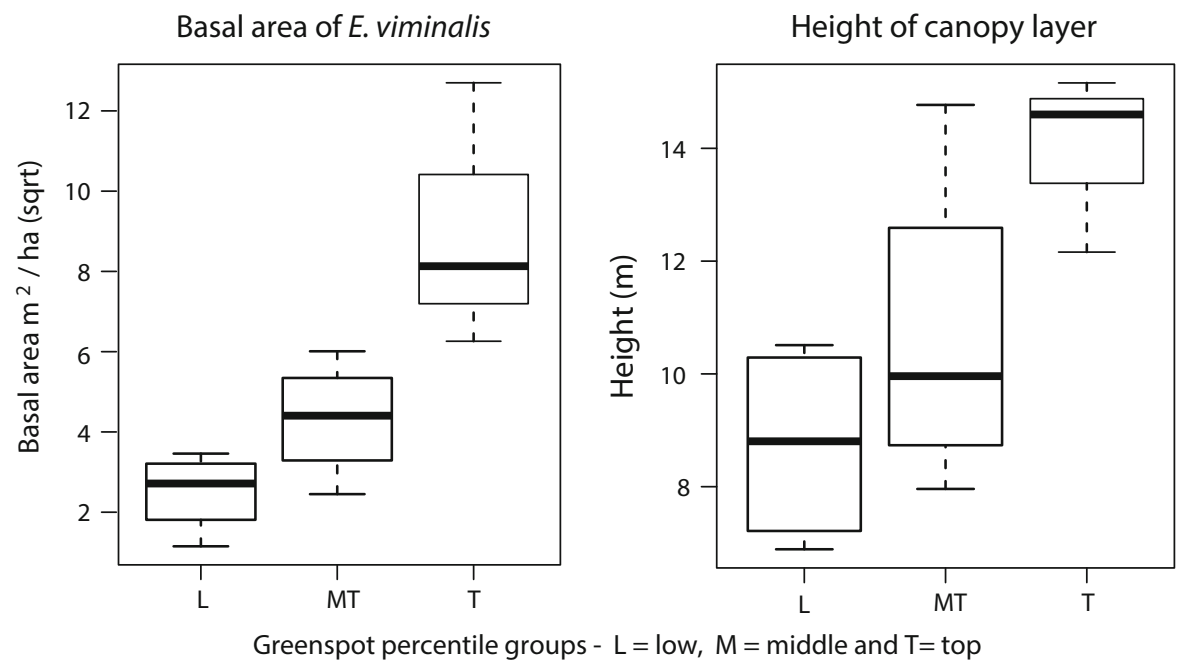

Fig. 4 Comparison of woodland vegetation structure. Box and whisker plots (showing the range, the interquartile range and the median) comparing canopy height and basal area of Eucalyptus viminalis between woodland greenspot groups

had data for 11 grassland sites (Table 1). For these sites, values for the basal area of the grassland framework species, T. triandra and basal area of tussock grasses were positively related to the coefficient of variation of monthly mean fPAR but not long term mean fPAR (Table 3). It is noteworthy that even in the subset of "pure" grassland sites there was still considerable spatial variation in the composition and structure of the grassland greenspots with the inclusion of small patches of saline herbland, wetland and lowland grassland complex within sites mapped as lowland T. triandra grasslands. Given the vegetation classification error and the spatial heterogeneity within the remaining grassland sites our grassland vegetation data probably do not accurately represent a productivity gradient of Lowland $T$. triandra grasslands.

\section{Covariates of the woodland greenspot index}

The spatial distribution of woodland greenspot groups in the Northern Midlands was significantly correlated with climatic and landscape variables. Rainfall explained most of the variation followed by the index of plant available water capacity which contains information about soil texture and soil depth among other attributes (Table 2). The scaled variable importance values were rainfall (89), plant available water capacity (7), slope (3) and topographic position (1).
There was interaction between explanatory variables so that the distribution of woodland greenspots varied as a function of rainfall, plant available water capacity, slope and topographic position. There were four distinct sets of conditions in which there was $>25 \%$ chance that woodland greenspots would be in the highest group. For example, in locations where annual mean rainfall exceeded $786 \mathrm{~mm}$, high woodland greenspots were associated with low, i.e., $<0.2$ plant available water capacity. In contrast, where annual mean rainfall was less than $578 \mathrm{~mm}$, high woodland greenspots occurred in locations where topographic aspect was southeast and $0.36<$ plant available water capacity $<0.4$. Between 578 and $786 \mathrm{~mm}$ annual mean rainfall, high woodland greenspots were more likely to occur in locations where topographic slope $>14^{\circ}$ and topographic aspect was south-southeast.

\section{Discussion}

The woodland greenspot index was a good predictor of variation in the basal area, and hence biomass, of the framework species, E. viminalis. The long term mean fPAR was a better predictor of variation in vegetation structure than the coefficient of variation of monthly mean fPAR. We conclude that the ecosystem greenspot method is informative about the biomass of specific vegetation based habitat resources in woody 
vegetation. The ability to provide high resolution information about gradients of specific vegetation based habitat resources has immediate applications for conservation planning. Conservation planning is informed, among other things, by the scientific criteria of comprehensiveness, adequacy and representativeness (Commonwealth of Australia 1999). The criterion of representativeness includes consideration of the need to protect variability in the quality of habitats within ecosystems. The information provided by the ecosystem greenspots index has potential application in assessing how representative the protected area estate is with respect to habitat quality. A similar approach has been used to assess spatial bias in protection of and threats to biodiversity in Canada (Andrew et al. 2011). The ability to identify the most productive locations of specific vegetation based habitat resources may also be a useful tool for species level conservation planning.

The ecosystem greenspot method as applied here was not successful for grasslands. To begin, there was a high error rate in grassland classification. Furthermore, there were no gradients in the biomass of the framework species, T. triandra. Most of the identification error was due to the use of the vegetation data at the spatial scale of $250 \mathrm{~m}$. Use of the data at this resolution meant that there were errors in the location of vegetation boundaries and in vegetation classification. Some classification error was also caused by the method we used to classify vegetation when transforming it from vector data into raster data. These combined sources of error resulted in the inclusion of non-grassland vegetation which distorted the ecosystem greenspots index for grasslands. More work is needed to address sources of error and field validation methods for grassy ecosystems in the Midlands of Tasmania.

The finding that the coefficient of variation of mean monthly fPAR was positively correlated with the basal area of $T$. triandra and the basal area of tussock grasses is counter to our expectation. We predicted that the basal area of framework species would increase as temporal stability increased i.e., as the coefficient of variation decreased. There are a few factors that may contribute to this finding. First, the vegetation data in grasslands is confounded by land management with variation in grazing regimes between sites. Second, specific components of the total vegetation cover may account for different fractions of the fPAR signal.
Different leaf functional types exhibit different temporal dynamics which account for different components of the total fPAR signal (Berry and Roderick 2002). Given the amount of variation in grassland vegetation a larger sample size is needed to clarify the relationships. Furthermore, any future field work will need to consider testing different fractions of the fPAR signal.

Conversion of land to agriculture in the Northern Midlands has primarily occurred on valley fill, valley slopes and colluvial fill. This land use history results in a spatial bias in our analysis of factors driving the spatial distribution of greenspots. Nevertheless, our analysis of the environmental correlates of greenspots indicates that soil texture, soil depth, topographic slope and topographic position interact with regional climatic conditions. These interactions modify light, temperature and soil moisture regimes at a topographic scale in ways that enhance plant soil water availability, a key constraint on rates of photosynthesis. Thus the spatial distribution of ecosystem greenspots is to some extent spatially fixed by intrinsic variables. Given that precipitation deficit and surplus conditions, relative to the 1961-1990 baseline period, are projected to occur more frequently over much of Tasmania over the twenty-first century (A2 scenario) (White et al. 2010), intrinsic variables that can buffer sites from moisture stress will be potentially more important in the future.

The concepts of spatial insurance, conservation capacity and vulnerability to climate change that have been discussed in relation to conservation planning (Gillson et al. 2013), rely on a largely spatial approach to conservation. An important feature of the ecosystem greenspots method is that it provides information about temporal dynamics in vegetation productivity. The ability to identify locations that exhibit low temporal variation in vegetation productivity during drought conditions is potentially a powerful conservation planning tool in the context of climate change. Given the projections of increasing variability in climatic conditions, locations that remain productive during drought conditions may function as drought micro-refuges. Supporting evidence of the importance of temporal variation in productivity to habitat quality comes from faunal demographic studies (Gunnarsson et al. 2005; Wiegand et al. 2008). We suggest that conservation planning should explicitly consider temporal variation in habitat quality, particularly 
when exploring options for mitigating the impacts on biodiversity of projected future climate.

Acknowledgments We gratefully acknowledge L. Gilfedder and O. Carter (Tasmania Department of Primary Industries, Parks, Water and Environment) for their knowledgeable advice in early stages of planning the research and the substantial assistance they provided with field work logistics. S. Gaynor provided assistance with field work logistics. R. Thorn provided technical assistance. K. Mitchell provided helpful instructions on calculating stem densities. This research is an output from the Landscapes and Policy Research Hub which is funded from the Australian Government's National Environmental Research Programme.

Open Access This article is distributed under the terms of the Creative Commons Attribution License which permits any use, distribution, and reproduction in any medium, provided the original author(s) and the source are credited.

\section{References}

Andrew ME, Wulder MA, Coops NC (2011) Patterns of protection and threats along productivity gradients in Canada. Biol Conserv 144:2891-2901

Andrewartha HG, Birch LC (1984) The Ecological Web: more on the distribution and abundance of animals. University of Chicago Press, Chicago

Ashcroft MB (2010) Identifying refugia from climate change. J Biogeogr 37:1407-1413

Ashcroft MB, Chisholm LA, French KO (2009) Climate change at the landscape scale: predicting fine-grained spatial heterogeneity in warming and potential refugia for vegetation. Glob Chang Biol 15:656-667

Ashcroft MB, Gollan JR, Warton DI, Ramp D (2012) A novel approach to quantify and locate potential microrefugia using topoclimate, climate stability, and isolation from the matrix. Glob Chang Biol 18:1866-1879

Berry SL, Roderick ML (2002) Estimating mixtures of leaf functional types using continental-scale satellite and climatic data. Glob Ecol Biogeogr 11:23-39

Berry SL, Roderick ML (2004) Gross primary productivity and transpiration flux of the Australian vegetation from 1788-1988 AD: effects of $\mathrm{CO}_{2}$ and land use change. Glob Chang Biol 10:1884-1898

Berry S, Mackey B, Brown T (2007) Potential applications of remotely sensed vegetation greenness to habitat analysis and the conservation of dispersive fauna. Pac Conserv Biol 13:120-127

Berryman AA, Hawkins BA (2006) The refuge as an integrating concept in ecology and evolution. Oikos 115:192-196

Bouldin J (2008) Some problems and solutions in density estimation from bearing tree data: a review and synthesis. J Biogeogr 35:2000-2011

Box EO (1989) Accuracy of the AVHRR vegetation index as a predictor of biomass, primary productivity and net $\mathrm{CO}_{2}$ flux. Vegetatio 80:71-89
Bureau of Meteorology (2013) Monthly climate statistics. http:// www.bom.gov.au/climate/averages/tables/cw_091022. shtml. Accessed 7 Aug 2013

Byrne M (2008) Evidence for multiple refugia at different time scales during Pleistocene climatic oscillations in southern Australia inferred from phylogeography. Quat Sci Rev 27:2576-2585

Carbone C, Gittleman JL (2002) A common rule for the scaling of carnivore density. Science 295:2273-2276

Carnaval AC, Hickerson MJ, Haddad CF, Rodrigues MT, Moritz C (2009) Stability predicts genetic diversity in the Brazilian Atlantic forest hotspot. Science 323:785-789

Caughley G (1994) Directions in conservation biology. J Anim Ecol 63:215-244

Commonwealth of Australia (1999) Australian guidelines for establishing the national reserve system. Environment Australia, Canberra

Coops NC, Wulder MA, Duro DC, Han T, Berry S (2008) The development of a Canadian dynamic habitat index using multi-temporal satellite estimates of canopy light absorbance. Ecol Indic 8:754-766

Dobrowski SZ (2011) A climatic basis for microrefugia: the influence of terrain on climate. Glob Chang Biol 17:1022-1035

Ellison AM, Bank MS, Clinton BD, Colburn EA, Elliott K, Ford CR, Foster DR, Kloeppel BD, Knoepp JD, Lovett GM, Mohan J, Orwig DA, Rodenhouse NL, Sobczak WV, Stinson KA, Stone JK, Swan CM, Thompson J, Von Holle B, Webster JR (2005) Loss of foundation species: consequences for the structure and dynamics of forested ecosystems. Front Ecol Environ 3:479-486

Engeman RM, Sugihara RT, Pank LF, Dusenberry WE (1994) A comparison of plotless density estimators using Monte Carlo simulation. Ecology 75:1769-1779

Enquist BJ, Brown JH, West GB (1998) Allometric scaling of plant energetics and population density. Nature 395:163-165

Enquist BJ, West GB, Charnov EL, Brown JH (1999) Allometric scaling of production and life-history variation in vascular plants. Nature 401:907-911

Gaggiotti OE, Hanski I (2004) Mechanisms of population extinction. In: Hanski I, Gaggiotti OE (eds) Ecology, genetics and evolution of metapopulations. Elsevier, London

Gates DM (1980) Biophysical ecology. Springer, New York

Gillson L, Dawson TP, Jack S, McGeoch MA (2013) Accommodating climate change contingencies in conservation strategy. Trends Ecol Evol 28:135-142

Gunnarsson TG, Gill JA, Newton J, Potts PM, Sutherland WJ (2005) Seasonal matching of habitat quality and fitness in a migratory bird. Proc R Soc B 272:2319-2323

Hennessy K, Fitzharris B, Bates BC, Harvey N, Howden SM, Hughes L, Salinger J, Warrick R (2007) Australia and New Zealand. In: Parry ML, Canziani OF, Palutikof JP, van den Linden PJ, Hanson CE (eds) Climate change 2007: impacts, adaptation and vulnerability, contribution of working group II to the fourth assessment report of the intergovernmental panel on climate change. Cambridge University Press, Cambridge

Hewitt GM (2004) Genetic consequences of climatic oscillations in the Quaternary. Philos Trans R Soc B 359:183-195 
Hothorn T, Hornik K, Zeileis A (2006) Unbiased recursive partitioning: a conditional inference framework. J Comput Graph Stat 15:651-674

Huete A, Didan K, Miura T, Rodriguez EP, Gao X, Ferreira LG (2002) Overview of the radiometric and biophysical performance of the MODIS vegetation indices. Remote Sens Environ 83:195-213

Hugall A, Moritz C, Moussalli A, Stanisic J (2002) Reconciling paleodistribution models and comparative phylogeography in the Wet Tropics rainforest land snail Gnarosophia bellendenkerensis (Brazier 1875). Proc Natl Acad SciUSA 99:6112-6117

Huston MA (1994) Biological diversity: the coexistence of species on changing landscapes. Cambridge University Press, Cambridge

Kearns AM, Joseph L, Cook LG (2010) The impact of Pleistocene changes of climate and landscape on Australian birds: a test using the Pied butcherbird (Cracticus nigrogularis). Emu 110:285-295

Keppel G, Van Niel KP, Wardell-Johnson GW, Yates CJ, Byrne M, Mucina L, Schut AGT, Hopper SD, Franklin SE (2011) Refugia: identifying and understanding safe havens for biodiversity under climate change. Glob Ecol Biogeogr 21:393-404

Krebs CJ (1997) Ecological methodology, 2nd edn. Addison Wesley Longman Inc., Menlo Park

Mackey B, Berry S, Hugh S, Ferrier S, Harwood TD, Williams KJ (2012) Ecosystem greenspots: identifying potential drought, fire, and climate-change micro-refuges. Ecol Appl 22:1852-1864

Magri D (2008) Patterns of post-glacial spread and the extent of glacial refugia of European beech (Fagus sylvatica). J Biogeogr 35:450-463

Mitchell K (2007) Quantitative analysis by the point-centred quarter method (version 2.15). http://people.hws.edu/ mitchell/PCQM.pdf. Accessed March 2013

Newton I (1994) The role of nest sites in limiting the number of hole-nesting birds: a review. Biol Conserv 70:265-276

Newton I (2004) Population limitation in migrants. Ibis 146:197-226

Newton I (2013) Bird populations. Harper Collins Publishers, London

Pollard JH (1971) On distance estimators of density in randomly distributed forests. Biometrics 27:991-1002

Prasad AM, Iverson LR, Liaw A (2006) Newer classification and regression tree techniques: bagging and random forests for ecological prediction. Ecosystems 9:181-199
Provan J, Bennett KD (2008) Phylogeographic insights into cryptic glacial refugia. Trends Ecol Evol 23:564-571

R Development Core Team (2005) R: a language and environment for statistical computing. R Foundation for Statistical Computing, Vienna

Roderick M, Noble IR, Cridland SW (1999) Estimating woody and herbaceous vegetation cover from time series satellite observations. Glob Ecol Biogeogr 8:501-508

Rull V (2009) Microrefugia. J Biogeogr 36:481-484

Scoble J, Lowe AJ (2010) A case for incorporating phylogeography and landscape genetics into species distribution modelling approaches to improve climate adaptation and conservation planning. Divers Distrib 16:343-353

Sellers PJ, Tucker CJ, Collatz GJ, Los SO, Justice CO, Dazlich DA, Randall DA (1994) A global $1^{\circ}$ by $1^{\circ}$ NDVI data set for climate studies. Part 2. The generation of global fields of terrestrail biophysical parameters from the NDVI. Int $\mathbf{J}$ Remote Sens 15:3519-3545

Southwood TRE (1988) Tactics, strategies and templets. Oikos 52:3-18

Stewart JR, Lister AM (2001) Cryptic northern refugia and the origins of the modern biota. Trends Ecol Evol 16:608-613

Stewart JR, Lister AM, Barnes I, Dalen L (2010) Refugia revisited: individualistic responses of species in space and time. Proc R Soc B 277:661-671

Sublette Mosblech NA, Bush MB, van Woesik R (2011) On metapopulations and microrefugia: paleoecological insights. J Biogeogr 38:419-429

Tasmanian Vegetation Monitoring and Mapping Program (2009) TASVEG 2.0 metadata. Tasmanian Vegetation Monitoring and Mapping Program, Department of Primary Industries, Parks, Water and Environment, Hobart

West GB, Brown JH (2005) The origin of allometric scaling laws in biology from genomes to ecosystems: towards a quantitative unifying theory of biological structure and organization. J Exp Biol 208:1575-1592

White CJ, Grose MR, Corney SP, Bennett JC, Holz GK, Sanabria LA, McInnes KL, Cechet RP, Gaynor SM, Bindoff NL (2010) Climate future of Tasmania: extreme events technical report. Hobart, Tasmania

Wiegand T, Naves J, Garbulsky M, Fernandez N (2008) Animal habitat quality and ecosystem functioning: exploring seasonal patterns using NDVI. Ecol Monogr 78:87-103 